6.5 measured 3 days after the reinitiation of treatment with zidovudine, but otherwise ophthalmic findings were normal, especially the values for deutan and protan vision. Two weeks later tritan colour contrast sensitivity was RE $3 \cdot 5$, and LE 3.8 and other findings were unchanged.

\section{Comment}

Alterations of colour vision have been reported for numerous drugs. ${ }^{112}$ Acquired alterations of tritan vision are usually related to retinal damage. ${ }^{13}$ Therefore, the dyschromatopsia in the two reported cases is expected to be related to retinal damage.

Recently, retinal damage has been reported for children treated with $2^{\prime}, 3^{\prime}$ - dideoxyinosine. ${ }^{14}$ The authors used electrophysiological methods to measure retinal function, but no tests for colour vision were performed. They suggest that $2^{\prime}, 3^{\prime}$-dideoxyinosine, which is also a dideoxynucleoside like zidovudine, causes a diffuse dysfunction of the retinal pigment epithelium.

The pathogenesis of colour vision deficits in patients with symptomatic HIV infection or AIDS remains unclear. It was proposed that the HIV-related retinal microangiopathic syndrome plays an important role in the pathogenesis of those colour vision deficits. Our observations suggest that a temporary shift in tritan colour vision is an adverse effect at the beginning of treatment with zidovudine. This shift in tritan vision might be due to a temporary interference of zidovudine with the production of visual pigment, or a temporary alteration of the pigment epithelium. Nevertheless, other factors may underly the changes. It cannot be ruled out that long term application of zidovudine might contribute to the development of colour vision deficits described for patients with HIV disease. Health care professionals involved in the treatment of patients with HIV disease should be aware of any abnormal drug or disease related effects.

This study was supported by Bundesministerium für Forschung und Technologie, and by Bundesministerium für Gesundheit, Germany, grant FKZ BGA III-002-89/FVP.

We wish to thank Mrs Ch Hörmann and Mrs cand med $\mathrm{H}$ Schmidt-Kittler for their help.

1 Corey L, Fleming TR. Treatment of HIV infection - progress in perspective. $N$ Engl f Med 1992; 326: 484-6.

2 Fischl MA, Richmann DD, Hansen N, Collier AC, Carey JT, Para MF, et al. The safety and efficacy of zidovudine (AZT) in the treatment of subjects with mildly symptomatic human in the treatment of subjects with mildy symptomatic human blind, placebo controlled trial. Ann Intern Med 1990; 112: 727-37.

3 Volberding PA, Lagakos SW, Koch MA, Pettinelli C, Myers MW, Booth DK, et al. Zidovudine in asymptomatic human immunodeficiency virus infection: a controlled trial in persons with fewer than 500 CD4-positive cells per cubic millimeter. $N$ Engl f Med 1990; 322: 941-9.

4 Hamilton JD, Hartigan PM, Simberkoff MS, Day PL, Diamond GR, Dickinson GM, et al. A controlled trial of early versus late treatment with zidovudine in symptomatic human immunodeficiency virus infection. $N$ Engl $f$ Med 1992; 326: 437-43.

5 Graham NMH, Zeger L, Park LP, Vermund SH, Detels R, Rinaldo CR, et al. The effects on survival of early treatment of human immunodeficiency virus infection. $N$ Engl $千$ Med 1992; 326: 1037-42.

6 Klutman NE, Hinthorn DR. Excessive growth of eyelashes in a patient with AIDS being treated with zidovudine [Letter]. a patient with AIDS being treated

7 Yarchoan R, Mitsuya H, Myers CE, Broder S. Clinical pharmacology of $3^{\prime}$-azido-2', $3^{\prime}$-dideoxythymidine (zidovudine) and related dideoxynucleosides. $N$ Engl f Med 1989; 321: 726-38.

8 Quiceno JI, Capparelli E, Sadun AA, Munguia D, Grant I, Listhaus $\mathrm{A}$, et al. Visual dysfunction without retinitis in patients with acquired immune deficiency syndrome. $A m \mathcal{F}$ Ophthalmol 1992;113: 8-13.

9 Geier SA, Berninger T, Kronawitter U, Bogner JR, Klauss V, Goebel F-D. Colour vision in AIDS patients and HIV positives. VIIth International Conference on AIDS, Florence, 16-21 June 1991. Abstractbook, Abstract MB 2417, 1991: 286.

10 Arden GB, Gündiz K, Perry S. Colour vision testing with a computer graphics system. Clin Vis Sci 1988; 2: 303-20.

11 Lyle WM. Drugs and conditions which may affect colour vision. Part I: Drugs and chemicals. F Am Optometric Ass 1974; 45: 47 .

12 Zrenner E. Neurophysiological aspects of colour vision in primates. In: Studies of brain function. Vol 9. New YorkHeidelberg: Springer, 1973.

13 Hart WM. Acquired dyschromatopsias. Surv Ophthalmol 1987; 32: 10-31

14 Whitcup SM, Butler KM, Caruso R, de Smet MD, Rubin B, Husson RN, et al. Retinal toxicity in human immunodeficiency virus-infected children treated with 2',3'dideoxyinosine. Am $\mathcal{F}$ Ophthalmol 1992; 113: 1-7.

\title{
Bilateral retinal haemorrhages following epidural injection
}

\author{
C Ling, P L Atkinson, C G F Munton
}

Kent County Ophthalmic and Aural Hospital, Church Street, Maidstone, Kent ME14 1DT C Ling P L Atkinson C G F Munton Correspondence to: Mr P L Atkinson, King's College Hospital, Denmark Hill, London SE5 9RS. Accepted for publication 12 January 1993
Epidural analgesia is widely used in the management of chronic back pain and in a variety of obstetric and surgical procedures and complications are well described. ${ }^{1}$ We report a case of bilateral retinal haemorrhages following caudal epidural injection under general anaesthesia for the relief of chronic back pain.

\section{Case report}

A 47-year-old woman underwent a caudal epidural injection and sciatic stretch under general anaesthesia for the relief of chronic back pain following a road traffic accident. A spinal decompression had been performed 2 years previously. She was generally well with no history of diabetes mellitus or hypertension and no eye problems apart from moderate right amblyopia. General anaesthesia was induced with propofol and maintained with nitrous oxide in oxygen. A sciatic stretch was performed and an injection of $80 \mathrm{mg}$ depomedrone in $20 \mathrm{ml}$ 
Figure 1 Fundus photographs showing retinal and preretinal haemorrhages. (A) Right eye, $(B)$ left eye.

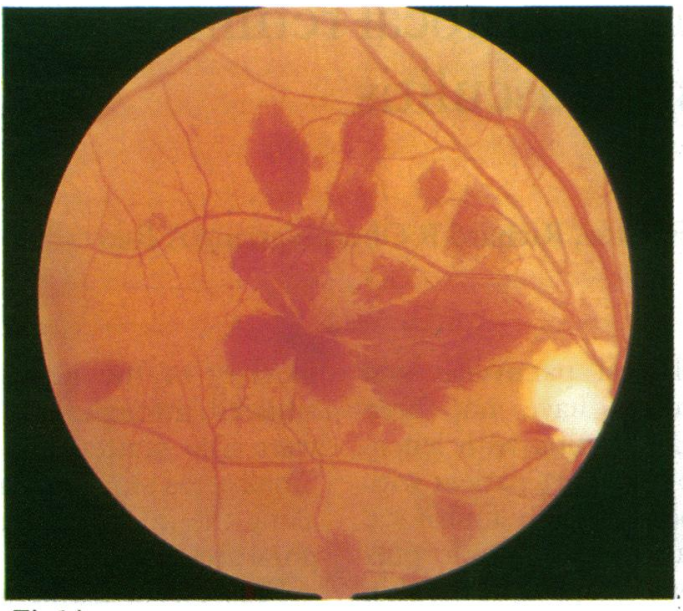

Fig $1 A$

$0.5 \%$ marcaine with $20 \mathrm{ml}$ normal saline made into the caudal epidural space. On recovery she noticed 'patches' obscuring her vision in both eyes. She had no headache.

On ophthalmic assessment 4 days following injection she was found to have a visual acuity of $6 / 60$ bilaterally with retinal and preretinal haemorrhages at both posterior poles centred on the macula (Fig 1). The optic discs and retinal vessels were normal and there was no posterior vitreous detachment. Blood pressure, blood sugar, full blood count, and clotting screen were normal. The haemorrhages cleared over the next 6 weeks with recovery to her previous vision of $6 / 6$ right and $6 / 18$ left by 3 months. Her fundi were normal with clinically normal retinal vessels.

\section{Comment}

Several mechanisms may be responsible for causing acute loss of vision following general anaesthesia. Pressure on the globe may lead to central retinal artery occlusion, ${ }^{2}$ and corneal endothelial dystrophy may decompensate to produce corneal oedema. ${ }^{3}$ Transient visual loss has also been described with the use of ketamine, ${ }^{4}$ and in association with glycine absorption during prostatic resection. ${ }^{5}$ Retinal haemorrhages diagnosed as Valsalva haemorrhagic retinopathy have been observed following laparoscopy and tubal insufflation performed in the Trendelenburg position with intermittent positive pressure ventilation. ${ }^{6}$ Only one previous case of retinal haemorrhages following epidural injection has been reported. ${ }^{7}$ This case has many similarities to ours in that bilateral retinal haemorrhages occurred following the injection of $40 \mathrm{ml}$ of fluid into the caudal epidural space under general anaesthesia for the relief of back pain. In both cases the patient was breathing spontaneously during the procedure. The authors postulated that the haemorrhages were caused by an increase in retinal venous pressure secondary to a rise in cerebrospinal fluid pressure produced by a sudden increase of pressure in the epidural space. This is supported by the work of Usubiaga et al who have demonstrated that a rise in cerebrospinal fluid pressure of up to $85 \mathrm{~cm} \mathrm{H}_{2} \mathrm{O}$ can be produced by the injection of $20 \mathrm{ml}$ of fluid into the lumbar epidural space. ${ }^{8}$ The size of the

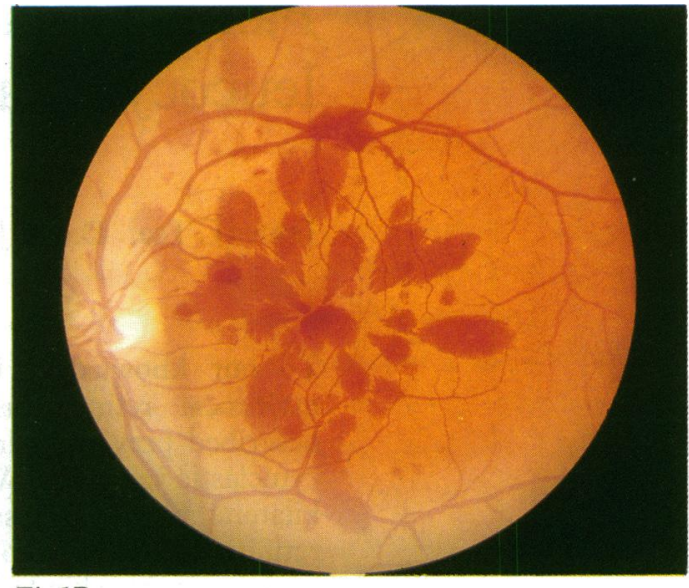

Fig $1 B$

pressure rise was proportional to the speed and volume of the injection.

The haemorrhages in our case are characteristic of those thought to be caused by 'backward' pressure on the retinal capillaries.' A similar fundal appearance is seen in Terson's syndrome and in Valsalva haemorrhagic retinopathy. The mechanism producing the retinal and vitreous haemorrhage in Terson's syndrome is thought to be an increase in retinal venous pressure secondary to a rise in cerebrospinal fluid pressure following a subarachnoid haemorrhage. ${ }^{9}$ In Valsalva haemorrhagic retinopathy a rise in intrathoracic venous pressure owing to violent coughing or compression of the chest or abdomen is believed to be directly transmitted to the retinal veins causing bleeding from the retinal capillaries. ${ }^{10}$ In our case anaesthesia proceeded uneventfully with no excessive coughing or straining. Although the sciatic stretch may have produced a transient rise in intrathoracic pressure we consider it more likely that the epidural injection was responsible for the production of the retinal haemorrhages.

The visual prognosis of retinal haemorrhages following epidural injection appears to be good, with spontaneously resolution of the haemorrhages and a return to pre-existing visual acuity being seen in both our case and the one previously reported case. Experimental evidence suggests that the risk of this complication may be minimised by reducing the rate and volume of injection. $^{8}$

1 Conway C. Neurological and ophthalmic complications of anaesthesia. In: Churchill-Davidson HC, ed. A practice of anaesthesia. Philadelphia: Saunders, 1978: 1021-31.

2 Givner I, Jaffe NS. Occlusion of central retinal artery following anesthesia. Arch Ophthalmol 1950; 43: 197-201.

3 Richardson RB, McBride CM, Berkeley RG, Derrick WS. An unusual ocular complication after anesthesia. Anesthesiology 1975; 43: 357-60.

4 Fine J, Weissman J, Finestone SC. Side effects after ketamine

5 Defalque RJ, Miller DW. Visual disturb.hces during transurethral resection of the prostate. Can Anaesth Soc $\mathcal{F} 1975$; 22: 620-1.

6 Bolder PM, Norton ML. Retinal haemorrhages following anesthesia. Anesthesiology 1984; 61: 595-7.

7 Victory RA, Hassett P, Morrison G. Transient blindness following epidural analgesia. Anaesthesia 1991; 46: 940-1.

8 Usubiaga JE, Usubiaga LE, Brea LM, Goyena R. Effect of saline injections on epidural and subarachnoid space pressure and relation to postspinal anesthesia headache. Anesth Analg 1967; 46: 293-6.

9 Duane TD. Retinopathy and distant extraocular trauma. In: Duane TD, ed. Glinical ophthalmology. New York: Harper and Row, 1979: Vol 3, Ch 32, 3-4.

10 Duane TD. Valsalva hemorrhagic retinopathy. Trans $\mathrm{Am}$ Ophthalmol Soc 1972; 70: 298-313. 